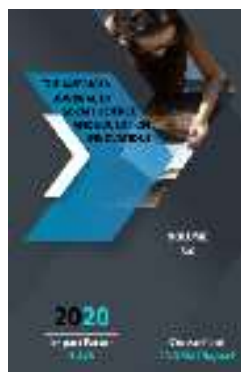

\title{
The Study Of Historical And Cultural Heritage: As An Epistemological And Socio-Philosophical Problem
}

\author{
Qoraboyeva Dildora
}

Researcher, National University Of Uzbekistan Named After Mirzo Ulugbek, Uzbekistan

Journal Website: http://usajournalshub.c om/index,php/tajssei

\section{ABSTRACT}

The article discusses some epistemological aspects of the study of historical and cultural heritage, as well as socio-philosophical issues of the relationship of historical and cultural heritage with the life of man and society. Epistemology is an area of philosophy concerned with the nature and justification of human knowledge. A growing area of interest for psychologists and educators is that of personal epistemological development and epistemological beliefs: how individuals come to know, the theories and beliefs they hold about knowing, and the manner in which such epistemological premises are a part of and an influence on the cognitive processes of thinking and reasoning.

\section{KEYWORDS}

History, historical and cultural heritage, culture, spirituality, society, epistemology, artifacts, wealth, succession, traditions, ethnic culture.

\section{INTRODUCTION}

Interest in historical and cultural heritage is at the heart of human epistemological research. Man's attitude to the world, the environment and society is a reflection of his attitude to the past, to the legacy left by the older generation. For example, the attitude of Socrates and Plato to the Sophists and the first philosophers is primarily epistemological. When Socrates says, "I knew what I did not know," he responds to the arrogant Sophists, reacting to their arrogance. "Don't let people hate you when you see your unfaithfulness to your parents, if 
you don't want to be friends, don't let people see your unfaithfulness to your parents, if you don't respect your parents, people may stop showing you kindness" [1; 90 b.]. In this context, Socrates means parents to the older generation, the moral norms and values he created. Parents, in his view, are the subjects of historical and cultural heritage, and their attitude to them is the attitude to this heritage.

Respect for and preservation of historical heritage has risen to the level of tradition and paradigm in Eastern philosophy, thought and way of life. The views of Confucius (551-479 BC) are noteworthy here.

Confucius insisted on governing the state and society based on the methods, moral norms, and historical traditions left by past generations. According to him, reliance on tradition is the main virtue of the "noble land". "The use of tradition brings people together. The methods of the ancient rulers were beautiful. They did their work, big and small, according to tradition" [2; s. 56]. The thinker argues that traditions, parents, and their heritage teach humanity, and that it is impossible to govern without being humane. He is a "noble land" humanist who sees himself as a socio-moral ideal. Confucius's political, philosophical, and moral views are aimed at epistemologically, such as revealing the functional properties of this "noble land" and its influence on the behavior of others. The "noble land" that governs the affairs of the state and society must first and foremost love and know the traditions and inculcate them in the people. In particular, the concept of "ideal governance" of thinkers - "governance, customs and order in society" ("Li") served for the important, sustainable development of society. In it, the idea of relying on historical and cultural traditions, ancestral experiences, principles of subordination in society, stratification in society, management, social and personal life - the essence of the concept of service, father and son "[3; 20-21 p.]. According to Professor F. Musaev, Doctor of Philosophy, Confucius' political and philosophical concept was "not to build a new, just society, but to reconstruct the past, to redefine historical and cultural experience." This is "historicism" in Confucius "[4; 18 b.].

One of the first scientific works on historical and cultural heritage is the work of Abu Rayhan Beruni (973-1048) "Monuments of ancient peoples." In it, the thinker approaches the past, historical and cultural traditions as a whole, creates unique epistemological methods of understanding and knowing them. He writes: "The closest thing to the reason for the questions I am asked is to know the events of past nations and past times. This is because most of the messages are descriptions of the states, images and laws of the past, and knowing them requires not only reliance on the intellect and comparison with the perceptible, but also on the People of the Book and the people of different opinions. In the course of history, it is necessary to compare their words and opinions" [5; 77 b].

Here Beruni points out the methods of scientific knowledge of epistemological significance. These include historical events, customs, Shari'a experience, rationality, comparing events and artifacts, reading books, studying, and relying on the thinking of peoples. These methods are still a priority in epistemology. Especially in the study of historical and cultural heritage, it is necessary to combine experience and reliance on rationality, as any experience, artifact and view 
of the past enriches the scientific philosophy and adds novelty to it when it meets the requirements of rationality.

Historical and cultural heritage means that we are connected to the past, and the new generation is always based on the riches, traditions and way of life left by previous generations. Friedrich Nietzsche (1844-1900) said, "We are chained to the past, wherever we run, the chain of history runs with us" [6; S.161] means that the spiritual riches created by man come from the spirit of the past. Man is "chained" to history and creates something new. When Newton was asked how he got to the law of universal gravitation, he replied that he was sitting on the shoulders of an adult.

Knowledge of historical and cultural heritage cannot remain at the level of epistemological experience, it must form a certain activity in the individual, make him an active subject by understanding the fundamental laws of social life, the requirements of development. Cognition does not remain in the category of "for itself", the improvement of social existence is the end result of any cognitive process. "Man's interest in knowing the world, the social being, should not be seen only as a subjective reality, as a necessity. It is true that cognition is always a sensitive, affective process of a subjective nature: human beings acquire knowledge only through their emotions ... Therefore, knowledge of the past, on the one hand, as a social reality of history, although subjective, the factor is necessary for evolutionary development. On the other hand, history does not exist "for itself." In knowing the historical truth, the person is given to certain abstractions, creates imaginary models and hypotheses. However, they do not remain abstract, they express not only the attitude of the individual to history, past events, but also to the readiness to assimilate and use existing historical and cultural experiences, to create a new historical space and social environment and to serve the development of society. "[7; 11-12 b.]. It is clear from these ideas that the study of historical and cultural heritage is, as Friedrich Nietzsche put it, "necessary for life and activity." "As we serve history, so it serves us" [6; S.159]. The ultimate result of this study is the creation of a new social space, a society that meets the fundamental goals of man and society.

The study, preservation and service of the historical and cultural heritage of Uzbekistan in the interests of the development of society is a task at the level of state policy. From the very first days of independence, Uzbekistan has linked its development with the restoration of historical and cultural heritage, reliance on the traditions of national statehood, spiritual and moral renewal, recognizing the priority of universal values. Building a new, independent, democratic, legal state based on historical and succession traditions has become a strategic goal.

\section{METHODS}

Historical and cultural heritage is a comprehensive phenomenon that applies to all spheres of social life. Everything about the people, the nation's spirituality, its past, its cultural artifacts, objects and views can be considered as objects of retrospective approach. Therefore, the historical and cultural heritage embodies the creative, moral and cultural riches of the generations before us. From a socio-philosophical point of view, they are:

1. Social and practical experience; 
2. Formed values;

3. Worldviews and ideas that are passed down from generation to generation;

4. Ethno-traditions in the form of a network.

It is known that the socio-practical experience of the people and the nation plays an important role in the historical and cultural heritage. As a result of such experiences, connections between generations are maintained and strengthened. For example, the Uzbek people have their own sociopractical experience of living in trade and economic relations with other nations and countries. As a result of these experiments, specific histories and directions of economic thinking, as well as methods and concepts that have contributed to the formation of today's market economy, have emerged. According to Professor A.Razzakov, "rare economic ideas and opinions have been formed in our country, sages and statesmen have a good idea of the important principles of a market economy, and on this basis have pursued economic policy. Labor is the basis of wealth, activity due to need, division of labor and its importance, price and its close connection with the market, functions of money and its role in the economy, free economic activity, tax system, usury, rent system, land and water relations, trade its importance, especially the sanctity of private property, the role of the state in the economy, and the need for a well-understood and strong state system of government" [8; 240 b.]. Such a socio-practical experience provides a broad, socio-philosophical approach to historical and cultural heritage.

Formed values are the norms, ideals, views, and customs that are respected in the life of man and society, that are unconditionally accepted, and that have social significance.
Such values form the core of the life of the people, the nation, and are considered as ethnocultural wealth. According to $\mathrm{O}$. Nishonova, Doctor of Philosophy, "ethno culture is the core of the epistemological research and experiments aimed at the artistic and aesthetic understanding of the material and spiritual wealth, values, artifacts and the world created by the people and the nation. The national culture and heritage have always been built on this core, through which it has acquired a national character, form and content" [9; 3 b.]. Thus, in the system of historical and cultural heritage, the values formed by the people, the nation, are central, and any presentation in this regard should reveal their place and significance.

\section{CONCLUSION}

Historical and cultural heritage is not an abstract thing, it always means a specific people, the traditions of the nation. There is no nation without ethno-traditions, but it is a matter of preserving them and directing them to spiritual and cultural development.

Thanks to the initiative and efforts of the President of the Republic of Uzbekistan Sh.M.Mirziyoev, a lot of work is being done to effectively use our ethno-traditions and spread them around the world. On measures to prepare for the International Music Festival "Sharq Taronalari" (February 26, 2019), "On measures to prepare for the II International Conference of Maqom Art" (February 26, 2019), "On the International Crafts Festival" "On measures to accelerate the development of the jewelry industry in the Republic of Uzbekistan" (May 18, 2019), "On holding the International Festival of Bakhchisarai” (November 1, 2018) - A completely new approach to cultural heritage. They claim that 
historical and cultural heritage is "a unique and great art" and "an incomparable spiritual wealth." "Such a unique and great art," says Sh.M.Mirziyoev, "is a bitter reality of our time, which today has become a mere cultural monument, forgotten in many places, in need of protection and preservation." Therefore, it is the duty of the world's leading scientists and artists, as well as statesmen and public figures, of all cultures to preserve and develop the art of classical baxshi, a rare example of folk art, which is our incomparable spiritual wealth, and pass it on to future generations". [10]

The head of our state is a supporter of the promotion and preservation of the art of boxing at the international level. More than 300 participants from 80 countries expressed their desire to participate in the festival, 58 of them with their own repertoire. The scientificpractical conference was attended by 45 foreign scientists and experts from 18 countries. It is important to note that this international festival is supported by UNESCO.

Thus, the historical and cultural heritage is not only a function of inheritance, it is the strengthening of international cultural ties, the formation of objective views about the people, the nation, instilling in young people a sense of respect for the past, the riches of our ancestors. It also fosters a desire to make a worthy contribution to development. This is the socio-philosophical essence of historical and cultural heritage.

\section{REFERENCES}

1. Entsiklopediya aforizmov. Antichnost. Drevnyaya Indiya. Drevniy Kitay. Bibliya. Minsk: Sovremen. literator., 1999.
2. Mudretsi podnebesnoy. - Simferopol, Renome, 1998.

3. Agzamxodjaeva S. ljtimoiy ideal va ma'naviy hayot. - Toshkent: Falsafa va huquq, 2007.

4. Musaev F. Demokratik davlat kurishning falsafiy-huquqiy asoslari. - Toshkent: O’zbekiston, 2007.

5. O'zbekistonda progressiv ijtimoiy-falsafiy fikrlar tarixiga doir materiallar. - Toshkent: Fan, 1959.

6. Nitsshe F. Sochineniya v dvux tomax. T.1. Misl, 1990.

7. Alimasov V.A., Xodjaeva B.X. Ijtimoiyma'naviy taraqqiyotda tarixiy shaxslarning roli. - Toshkent: «Fan va texnologiya», 2016.

8. Razzoqov A. Iqtisodiy tafakkur sarchashmalari. - Toshkent: O`zbekiston, 2011.

9. Nishonova O. O'zbek etnomadaniyatining estetik mohiyati. - Toshkent: Fan, 2013.

10. O'zbekiston Respublikasi Prezidenti Shavkat Mirziyoevning Xalqaro baxshichilik san'ati festivali ochilishiga bag'ishlangan tantanali marosimdagi nutqi. // Xalq so'zi, 2020 yil 7 aprel. 